\title{
A PEDAGÓguSOK SZAKMAI FEJLŐDÉSÉT, TANULÁSÁT MEGHATÁROZÓ RENDSZERSZABÁLYOZÁSI KÖRNYEZET
}

\author{
SZIVÁK JUDIT * - RÓNAY ZOLTÁN - SAÁD JUDIT - FAZEKAS ÁGNES \\ ELTE Pedagógiai és Pszichológiai Kar
}

A tanulmányban arra a kérdésre keressük a választ, hogy a hazai oktatás világát aktuálisan szabályozó rendszerkörnyezet miként orientálhatja a pedagógusok folyamatos szakmai fejlődését. Az elemzés az ELTE PPK Neveléstudományi Intézetében zajló, a pedagógusok folyamatos szakmai fejlődését vizsgáló OTKA-kutatás keretein belül született és elsődlegesen arra irányult, hogy feltárja, a vizsgált stratégiai és jogi szabályozó dokumentumokban a pedagógusok szakmai fejlődésével, tanulásával kapcsolatban milyen célok, elvárások fogalmazódnak meg, milyen támogatóeszközök segítik azok elérését, valamint milyen ellenőrző funkciók müködnek ezekhez kapcsolódóan. Az elemzés megállapította, hogy a szabályozó dokumentumokban a szakmai fejlődés alapvető kontextusa sokkal inkább az elvárás és annak ellenőrző mechanizmusai, mint a támogatott, autonómiára épített professziókép. Az egyes stratégiákban kevéssé látható a fejlesztéspolitika koherens és kifejtett koncepciója, sokkal inkább a közalkalmazotti kötelezettségek ellenőrző mechanizmusainak standardizáló rendszerei.

Kulcsszavakः pedagógusok szakmai fejlődése, köznevelési stratégia, jogszabályi környezet

In this study we are attempting to investigate how the existing national regulations of the educational system influence the constant professional development of teachers. This research was conducted in the Educational Institute of ELTE PPK as part of an OTKA project aiming to describe the constant professional development of teachers and was organized to uncover the effects of strategic and legal regulating documents on the goals and expectations of teacher's professional learning, on the support given to achieve these goals and on the supervisory functions. The study revealed that in the regulating documents the basic context of professional development is built much more on the requirements and their supervision, rather than on the image of a state-supported autonomous profession. Rarely could we identify coherent and clear concept of development, but the standardized mechanisms controlling the responsibilities of state employees.

Keywordsः professional development of teachers, educational strategy, legal environment

\footnotetext{
* Levelező szerző: Szivák Judit, ELTE Pedagógiai és Pszichológiai Kar, 1075 Budapest, Kazinczy u.23-25. E-mail: szivak.judit@ppk.elte.hu
} 


\section{Bevezetés}

$\mathrm{A}$ z alábbi tanulmányban arra a kérdésre keressük a választ, hogy vajon a hazai oktatás világát aktuálisan szabályozó rendszerkörnyezet miként orientálhatja a pedagógusok folyamatos szakmai fejlődését. A kapcsolódó elemzés az ELTE PPK Neveléstudományi Intézetében zajló, a pedagógusok folyamatos szakmai fejlödését vizsgáló OTKA kutatás keretein belül született, így e tanulmány is e kutatás részeredményeként értelmezhetö. ${ }^{1}$

Az elemzés elsődlegesen arra irányult, hogy feltárja, a vizsgált stratégiai és jogi szabályozó dokumentumokban a pedagógusok szakmai fejlödésével, tanulásával kapcsolatban milyen célok, elvárások fogalmazódnak meg, milyen támogatóeszközök segitik azok elérését, valamint milyen ellenörző funkciók müködnek ezekhez kapcsolódóan. A vizsgált dokumentumok a szabályozási környezet egészének áttekintésére törekedtek, így egyaránt sor került a köznevelési stratégiák és a kapcsolódó jogszabályok elemzésére.

\section{Köznevelési stratégiák}

A stratégiák megalkotásához kapcsolódó európai uniós programozási időszakban európai szinten jellemző volt a stratégiai irányítás növekedése, az implementációs folyamat tudatos és szakszerű tervezése. Felértékelődött a közös (tagállamok közötti) fejlődő tudás, egyre inkább biztosított a közös tudáshoz való könnyű hozzáférés. Jellemző volt a párhuzamosan zajló, hasonló nemzetközi erőfeszítések, tevékenységek tapasztalatainak felhasználása, az egymástól való tanulás nemzetközi, nemzeti és lokális szinteken is (Donaldson 2015; OECD 2017a, 2017b).

$\mathrm{A} z$ Európai Unió ennek érdekében 2008-ban elfogadott együttműködési programja ${ }^{2}$ felkéri a tagállamokat, hogy vizsgálják felül a pedagógusokkal kapcsolatos szakpolitikáikat. Az uniós dokumentumban a pedagógusok szakmai fejlődésének komplex képe bontakozik ki, amelyben hangsúlyosan jelennek meg a támogató elemek, az egyéni igényekre fókuszáló képzési programok minőségének és relevanciájának, valamint a hazai és nemzetközi hálózatosodás, tapasztalatcsere fontosságának fókuszba helyezésével.

\section{Jogszabályi környezet}

A $z$ oktatási rendszerekben is, mint minden más társadalmi rendszerben, jelentős szabályozó szerepet játszik a jog (Bíró 2018). A jogi szabályozás jelöli ki azokat a kereteket, amelyek a szerkezet, a tartalom, a foglalkoztatás felől jelentik az oktatási rendszerek müködtetésének feltételeit, a fejlesztési beavatkozások hatásmechanizmusait. Fontos kérdés, hogy egy köznevelési rendszer szabályozásában milyen szerepet kap a központi szabá-

1 A 128738 számú projekt a Nemzeti Kutatási Fejlesztési és Innovációs Alapból biztosított támogatással, a K_18 pályázati program finanszírozásában valósult meg. A rendszerkörnyezetet vizsgáló kutatócsoport tagjai: Szivák Judit, Fazekas Ágnes, Horváth László, Rónay Zoltán, Saád Judit, Salát Magdolna, Némethné Tóth Ágnes.

2 A Tanács és a tagállamok kormányainak a Tanács keretében ülésező képviselői által elfogadott következtetések (2008. november 21.) a fiatalok felkészítése a XXI. századra: az iskolák területén folyó európai együttműködés programjáról (2008/C 319/08). 
lyozás és a szakmai önszabályozás, a jogalkotás mennyiben kíván központi-előíró funkciója mellett építeni a szakmai szereplők autonómiájára, mennyiben érzékeny a rendszer aktorainak egyéni és szervezeti igényeire ${ }^{3}$, hogy a szabályozó eszközök és mechanizmusok komplexitása és koherenciája milyen mértékben támogatja az elérni kívánt hatások eredményességét, fenntarthatóságát (Mader 2001; Mousmouti 2019).

Magára a köznevelés világára, pedagógusokra vonatkozó szabályok rendkívül nagy számban fordulnak elö, összesen tizennégy jogszabály volt azonositható a pedagóguskép és a szakmai fejlödés témakörét érintő szabályozóként. E körben értelemszerüen a legfontosabb, egyszersmind kiindulópontot jelentő jogszabály a nemzeti köznevelésről szóló 2011. évi CXC. törvény (a továbbiakban: $\mathrm{Nkt}$ ).

Rendeleti szinten az egyik legmeghatározóbb jogszabály a pedagógusok előmeneteli rendszeréről és a közalkalmazottak jogállásáról szóló 1992. évi XXXIII. törvény köznevelési intézményekben történő végrehajtásáról szóló 326/2013. (VIII. 30.) Korm. rendelet (a továbbiakban: Nkt. Vhr.), amely az Nkt.-ban meghatározott foglalkoztatási előírások részletszabályait tartalmazza, részben önállóan, részben a közalkalmazottak jogállásáról szóló 1992. évi XXIII. törvény rendelkezéseit a sajátos pedagógusfoglalkoztatásra alkalmazva. Az Nkt. Vhr. a Köznevelési stratégiában megfogalmazott elvárásrendszerhez és az abban domináló, a támogatást is az ellenőrzés révén megvalósító logikához illeszkedve kógens és merev szabályokat kínál a munkáltatói jogkört és a fenntartói hatáskört gyakorló számára. A nevelési-oktatási intézmények müködéséről és a köznevelési intézmények névhasználatáról szóló 20/2012. (VIII. 31.) EMMI rendelet alapvetően az intézmény müködése során jogokat gyakorló és kötelezettségeket teljesítő személyekként azonosítja - mások mellett - a pedagógusokat is, akik mint a tevékenységük ellátására irányuló ellenőrzési mechanizmusok alanyai jelennek meg.

\section{A pedagógusok szakmai fejlődése és az ezt meghatározó rendszerkörnyezet}

A stratégiai és jogi környezet rövid bemutatása után áttérünk ezek néhány kiemelt perspektívákból történő mélyebb elemzésére. A vizsgálati fókuszokat a bevezetőben ismertetett tartalmi területek adták (1. célok, 2. tanulásértelmezés, 3. támogatórendszer, 4. ellenőrzés), az eredmények ismertetése is e fókuszok mentén történik.

\section{Célok a pedagógusok szakmai fejlödését, tanulását meghatározó rendszerkörnyezet szabályozási dokumentumaiban}

A köznevelési stratégia célkitüzései mentén kibontakozó pedagógusprofesszió elvárásai korszerü, a nemzetközi - és így a hazai fejlesztési - trendekkel összhangban álló, néhol idealizált pedagógus professzióképet jelenít meg: egy önreflektív, motivált, problémamegoldó, folyamatosan tanuló szakember képe bontakozik ki, miközben nehezen megragadható, hogy ehbez milyen konkrét, fokozatos, egymásra épülö intézkedésekre, beavatkozásokra van szükség.

A társadalom (az érintettek) bevonása a jogalkotásba a jogállamiság alkotóelemét képező jogbiztonság kritériuma (Isensee-Kirchbof 2004). 
A stratégia a professzió változásának követelményeit hangsúlyosan kezeli, a pedagógusok szakmai fejlődésének célját azonban nem kapcsolja mindezekhez következetesen, a szakmai fejlődést a célmeghatározásban deklaráltan az ellenőrző funkcióhoz köti.

A Nemzeti Oktatási Innovációs Rendszer kiegészített stratégiája (NOIR+) ${ }^{4}$ a hazai életpályarendszer a mester- és kutatópedagógus szerepet orientálja, és néhány tényező mentén nyilatkozik egy átfogónak mondható pedagógusképről is. Talán a legfontosabb a dokumentum által jelzett általánosan érvényes pedagógustulajdonságok közül az, hogy a stratégia minden pedagógust kutatást végzö szakemberként értelmez.

A javaslat kiemelten épít a mester-és kutatópedagógusok tudásközvetitö, újitásokat inspiráló és értékelö szerepére, mélyen elemzi a fejlesztési rendszerkörnyezetet és annak hatásait, a megjelölt célokat és elvárásokat ennek alapján fogalmazza meg. A stratégia szerint a mester- és kutatópedagógusok olyan „tanulás specialisták”, akik képesek kreatív megoldások kidolgozására, azok monitorozására és megosztására.

$\mathrm{A} z$ Nkt. a pedagógusok szakmai fejlődése, tanulása kapcsán célként, elvárásként a képzéseken, továbbképzéseken való részvételt fogalmazza meg. Ez ugyan jogként is megjelenik, de elsősorban munkavállalói (közalkalmazotti) kötelezettségként definiálódik. Ennek alapján - és általánosságban is - a tanárképben két elem dominál: egyrészt a tanár a köznevelési rendszer egy eleme, az elvárások elsődlegesen a köznevelés mint közszolgálat és közszolgáltatás szintjén fogalmazódnak meg, a rendszerrel és az azt alkotó intézmények müködésével szemben, amelyben alkotóelemként van jelen a pedagógus. Következésképp, és ez a második elem, elsősorban a közszolgáltatást nyújtó alkalmazott képe rajzolódik ki és nem egy autonóm véleményformáló értelmiségié, akinek kulcsszerepe van a jövő nemzedékének nevelésében, és aki erre tekintettel érdekelt, ösztönzött és támogatott az egyéni szakmai fejlödésben. Ennek következtében tanulási eredményeket nem fogalmaz meg. A Nkt. Vhr. is szigorú előmeneteli és számonkérési rendben foglalkoztatott alkalmazottként definiálja a pedagógust. Mindez azt is mutatja, hogy a pedagógus szakmai fejlődése a jogalkotó felfogásában egy szigorúan szabályozott munkajogi folyamat, amelynek minden állomása és azok teljesítése közigazgatási jellegű szabályozással rendezett. A köznevelési stratégia szerinti korszerü és komplex kép, explicit célként a folyamatos szakmai fejlödés nem jelenik meg benne.

\section{A pedagógusok tanulása a pedagógusok szakmai fejlödését, tanulását meghatározó rendszerkörnyezet szabályozási dokumentumaiban}

A köznevelési stratégia összességében komplex, a formális és informális tanulás lehetöségeit is számba vevő tanulásértelmezést tartalmaz. A baladó szemléletü, egész életen át tartó, tanulóközösségben aktív „tanuló pedagógus” céltételezése mellett a hozzárendelt beavatkozások és eszközök szükössége jellemző, a fentiek kapcsán a korábban kifejlesztett pedagógustovábbképzési tartalmak felülvizsgálatának, illetve új képzési hiányterületekre való reagálásának a szükségessége fogalmazódik meg.

\footnotetext{
4 Lásd: Kovács (2015).

5 „..»minden osztálytermet laboratóriumnak kell tekinteni és minden pedagógust egy kutató közösség tag jának« (Burton-Bartlett 2005: 35) [...] eredményes tanulást támogató tanulási környezetet teremteni csak olyan pedagógus-attitűd mellett lehetséges, amelyet a téma ismert kutatói a »kereső « jelzővel (inquiry stance) írtak le" (Kovács 2015: 35-39).
} 
A korábbi stratégiai dokumentumokat meghaladva a NOIR+ a pedagógusok tanulását olyan folyamatként értelmezi, amelynek elsődleges célja a szakmai gyakorlati tudás tudatos menedzselésére való képesség erősitése, az új tudások létrehozásának, megosztásának és terjesztésének elösegitése. Az eltérö tudásformák közül a tacit, procedurális tudás, és ezen belül pedig a társas tudás értékelödik fel e rendszerben: a dokumentum kiemelten kezeli a gyakorlatközösségekben folyó, közös informális tanulást, az ennek során keletkező és terjedő tudást tekinti az osztálytermi folyamatok menedzselése szempontjából mélyreható és a pedagógiai folyamatok eredményességét segítő tudásnak.

A z Nkt. tanulási/szakmai fejlődési folyamatokat lényegében nem határoz meg, ilyen mélységbe nem terjed a szabályozás hatálya. A részletes szabályok rögzítését az Nkt. Vhr.-re bízza, amely azonban a tanulási folyamatot kizárólag a pedagógus életpálya szakaszain való haladás, az egyes szakaszokhoz szükséges teljesítések szempontjából értelmezi.

\section{Támogatás megjelenése a pedagógusok szakmai fejlödését, tanulását meghatározó rendszerkörnyezet szabályozási dokumentumaiban}

A köznevelési stratégia a pedagógusok folyamatos szakmai fejlődése kapcsán átfogó, alaposan átgondolt és korszerü szemléletet tükröz. A pedagógusok egyéni szakmai fejlődése érdekében több területen fogalmazza meg a támogató beavatkozásokat (szaktanácsadói rendszer fejlesztése, horizontális tanulás lehetőségeinek bővítése, életpályán való előrehaladáshoz szükséges tudás megszerzésének támogatása stb.).

Konkrét eredményként ugyanakkor csupán a Klebelsberg Képzési Ösztöndíj bevezetése említődik, nem jelenik meg expliciten, hogy a minősítési rendszer továbbfejlesztése az ellenőrző funkciók mellett hogyan szolgálna fejlesztési célokat. A módszertani képzéseken túl személyiségfejlesztésre irányuló, kiégést megelőző/kezelő képzések, illetve az alkotóév feltételeinek kidolgozása is megjelennek a szakmai fejlödést támogató elemek között. Ugyanakkor az önmagukban haladó szemléletet tükröző támogató elemek nem koherens koncepcióban, hanem gyakran csak egy-egy részterület vonatkozásában köszönnek vissza.

Összességében tehát a köznevelési stratégiában a fejlesztési beavatkozásokhoz rendelt támogató funkciók, amelyek a sikeres implementáció alapvető feltételei csak sporadikusan, gyakran egy-egy részterülethez kapcsolódóan jelennek meg, és a pedagógus életpálya első szakaszán túl konkrét beavatkozások nem kapcsolódnak ezekhez.

A NOIR+ stratégia a pedagógusok tanulásának támogatása érdekében három olyan beavatkozási területet javasol, amelyek lefedik a jelenlegi tudásunknak megfelelö, a pedagógusok tanulásának leghatékonyabb külső támogatási eszközeit. E beavatkozási területek 1) a pedagógusmunka professzionalizálódásának támogatására, 2) a tudásmegosztás és a tudásmenedzsment rendszerek fejlesztésére és 3) az iskolai szervezetfejlesztés támogatására irányulnak. A tudásmegosztás és a tudásmenedzsment rendszerek fejlesztését segítő beavatkozási elemek a hálózati tanulás különböző színtereinek biztosítását, illetve a pedagógusok felfedező tanulásának értékelési kereteit fektetik le, míg a harmadik beavatkozási terület a pedagógusok tanulását szervezeti dimenzióból közelíti meg, illetve a munkahelyi környezet fejlesztése révén támogatja azt. 
Az Nkt. lényegében nem rendelkezik a tanulási környezet feltételrendszeréröl, ennek megfelelően nem szól a támogató elemekről, szereplőkről, erőforrásokról sem, a szakmai fejlődés támogatása a végrehajtási rendeleti szintjén sem jelenik meg.

\section{Ellenőrzés megjelenése a pedagógusok szakmai fejlödését, tanulását meghatározó rendszerkörnyezet szabályozási dokumentumaiban}

A köznevelési stratégia egyik deklarált célja a standardizálás, amely a hatékonyság és elszámoltathatóság, így akár a fejlesztés irányába is hathat, azonban egy olyan központi irányítású rendszerben, mint a magyar oktatás, a megfelelő támogató-fejlesztő funkciók kialakítása nélkül a szándékolt hatástól eltérhetnek a valóságos folyamatok.

Célként jelenik meg a stratégiában az egységes minöségértékelési eszközök kialakitása és alkalmazása, a pedagógus előmeneteli rendszerhez kötődő minősitési rendszer és a tanfelügyelet keretében történő ellenörzés összhangjának finomhangolása a működési tapasztalatok alapján. A tervezett intézkedések is elsősorban az ellenőrző funkcióhoz kapcsolódnak.

A NOIR+ stratégia leszögezi, hogy az értékelés során a tényleges hatások feltárása a cél, melynek érdekében az értékeléseknek alkalmazkodniuk kell a megvalósítási folyamatok komplex természetéhez. A javasolt beavatkozási területek között szerepel egy olyan mérési rendszer kidolgozása, amely a pedagógusok innovációs kompetenciáira, illetve kompetenciaváltozásainak mérési rendszerére irányul. A stratégiában az ellenőrzési rendszer csak nagy körvonalaiban meghatározott, a tervezet egyaránt utal a rendszerszintü folyamatok értékelésére, a nemzetközi összehasonlítás lehetőségének kihasználására, és olyan felhasználási területekre, mint a fejlesztések megalapozása, a politikák „számon kérhetősége".

$A z$ Nkt. rendszerében az ellenörzés a minösitö vizsga, amely sikeressége az elömenetel feltétele, sikertelensége vagy elmulasztása munkajogilag szankcionált. Minthogy a pedagógusok folyamatos szakmai fejlődésébe ágyazott tanulási folyamat kizárólag a pedagógus életpálya szakaszain való haladás tekintetében értelmezett, az ellenőrzés egyértelmüen munkajogi jellegü, jutalmazási és szankciórendszere ennek megfelelő. Ugyanígy az eljárásrend is igazgatási jellegü, abban a követelményeknek megfelelés vizsgálata, azaz a megfelelés vagy annak hiányának megállapítása dominál (Rónay 2019). Alapvetően szummatív legfeljebb egyes elemeiben diagnosztikus - jellegü, fejlesztő elem, jobbító visszajelzés nincs (vö. Báthory 1978; Scriven 1967; Lénárd-Rapos 2009).

\section{A folyamatos szakmai fejlödés modellje a hazai szabályozási dokumentumok elemzése alapján}

A pedagógusok folyamatos szakmai fejlődésének perspektívái rendszerszinten legalább három tényező koherens, egymást támogató jelenlétét igénylik: 1) világosan megfogalmazott koncepciózus célok, elvárások (tanulási eredmények), 2) az elvárások megvalósitását segitő támogató folyamatok és 3) az eredmények visszacsatolását biztositó ellenőrzési-értékelési rendszer (Goodson-Hargreaves 1996; Evetts 2011). A szabályozási dokumentumok elemzése alapján összességében megállapíthatjuk, hogy a hazai rendszerkörnyezet fenti három pillére nem azonos mértékben azonosítható a pedagógusok szakmai fejlődéséhez kötő- 
dően. Bár van olyan stratégiai dokumentum, amely megalapozott és korszerű koncepció mentén jelöli ki a fejlődési beavatkozások pillérjeit (NOIR, NOIR+), a célok, elvárások meghatározása mögött nincs olyan szakmapolitikai modell, amely következetesen megjelenne a szabályozás különböző szintjein és világos iránytűként szolgálna a rendszer különböző szintjein lévő cselekvések és szereplők számára. A támogatás folyamatai és operatív elemei hangsúlytalanok és kidolgozatlanok az ellenörzés minden szinten aprólékosan szabályozott rendszerébez képest (tanfelügyelet, önértékelés, minősítés). Az arányok eltolódását az 1. ábra szemlélteti.

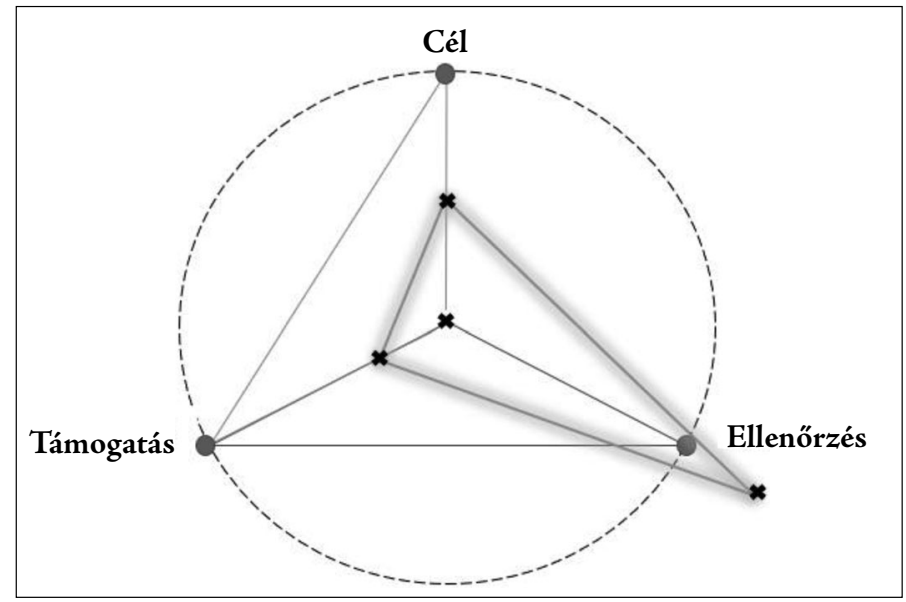

1. ábra: A pedagógusok folyamatos szakmai fejlődésének rendszerszintű tényezői és azok eltolódása Magyarországon

\section{Összefoglaló}

A köznevelés fejlesztési stratégiáját meghatározó szabályozó dokumentumok, az uniós fejlesztésekkel összhangban, összességében kiemelt célként kezelik a pedagógusok folyamatos szakmai fejlődését, elsősorban a pálya professzionalizálásához és vonzóvá tételéhez kötődően. A stratégiai dokumentumokban megragadható pedagóguskép korszerü, tartalmazza a szakmai fejlődés kritériumát, ugyanakkor a fejlődés mint átfogó koncepcionális elem a NOIR + stratégia kivételével nem bontakozik ki a dokumentumokban. A szakmai fejlödés alapvetö kontextusa sokkal inkább az elvárás és annak ellenörző mechanizmusai, mint a támogatott, autonómiára épitett professziókép. Az egyes stratégiák a szakmai fejlődési célok megfogalmazásában szinergiára törekszenek az uniós és a köznevelési stratégia célrendszerével, összességükben azonban kevéssé látható a fejlesztéspolitika egységes és kifejtett koncepciója, sokkal inkább a közalkalmazotti kötelezettségek ellenőrző mechanizmusainak jól definiált rendszerei jelennek meg bennük. Általánosságban elmondható, hogy a stratégiák deklarált célja a standardizálás, amely akár a fejlesztés irányába is hathatna a megfelelö támogató-fejlesztő funkciók összekapcsolásával. 
A rendeletek szintjén hasonló módon jellemezhető a szabályozás, amely a tanulás jelentőségének elismerése mellett csak a tanulás formális tényezőit veszi figyelembe. A jogszabályok, rendeletek eljárásrendjei igazgatási jellegűek, azokban a követelményeknek megfelelés vizsgálata dominál, az ellenőrzéshez kötődő tartalmak egyértelmüen a leggazdagabban kidolgozottak.

A pedagógusok tanulásának leghatékonyabb, rendszerszintű elemei, a fejlesztési beavatkozások és feltételek koherens stratégiája a NOIR+-ban jelennek meg a professzióhoz, a tudásmenedzsment rendszerekhez és a szervezeti kontextushoz kötődően. A stratégia e tekintetben (is) lényegében pontos fókuszokat definiál a pedagógusok szakmai fejlődésének makro- és mezozintű támogatására.

\section{IRODALOM}

2011. évi CXC. törvény a nemzeti köznevelésröl.

20/2012. (VIII. 31.) EMMI rendelet a nevelési-oktatási intézmények múködéséről és a köznevelési intézmények névhasználatáról.

326/2013. (VIII. 30.) Korm. rendelet a pedagógusok előmeneteli rendszeréről és a közalkalmazottak jogállásáról szóló 1992. évi XXXIII. törvény köznevelési intézményekben történő végrehajtásáról.

A Tanács és a tagállamok kormányainak a Tanács keretében ülésező képviselői által elfogadott következtetések (2008. november 21.) a fiatalok felkészítése a XXI. századra: az iskolák területén folyó európai együttmüködés programjáról (2008/C 319/08).

BÁthory Z. (1978) A pedagógiai értékelés és annak tantervi alkalmazása. Magyar Pedagógia, Vol. 78. No. 2. pp. 195-207.

Bíró E. (2018) Bilincs vagy kilincs?! Budapest, Jogismeret Alapítvány.

Donaldson, G. (2015) Successfull Futures. Independent Rewiev of Curruculum and Assesment Arrangements in Wales. OGL. https://www.nasuwt.org.uk/asset/A788604C-3046-4005A1EA0EAFF023E0DD/ [Letöltve: 2019. 11. 17.]

Evetts, J. (2011) A New Professionalism? Challenges and Opportunities. Current Sociology, Vol. 59. No. 4. pp. 406-422.

Goodson, I. F. \& Hargreaves, A. (1996, eds) Teachers' Professional Lives. London, Falmer Press.

Isensee, J. \& Kirchiof, P. (2004) Handbuch des Staatsrechts. Band II. Heidelberg, Verfassungsstaat.

Kovács I. V. (2015, ed.) „OKOS KÖZNEVELÉS” Javaslat a Nemzeti Oktatási Innovációs Rendszer stratégiájának kiegészitésére. „NOIR+Stratégia” http://halaszg.of.hu/ download/A_NOIR_plusz_\%282015.07.26\%29.pdf [Letöltve: 2019. 11. 17.]

LénÁrd S. \& Rapos N. (2009) Fejlesztó értékelés. Budapest, Gondolat.

Mader, L. (2001) Evaluating the Effects: A Contribution to the Quality of Legislation. Statute Law Review, Vol. 22. No. 2. pp. 119-131.

Mousmouti, M. (2019) Designing Effective Legislation. Camberley Surrey, Edward Elgar Publishing.

OECD (2017a) The Welsh Education Reform Journey. A Rapid Policy Assessment. Paris, OECD Publishing. https://www.oecd.org/education/The-Welsh-Education-ReformJourney-FINAL.pdf [Letöltve: 2019. 11. 17.] 
OECD (2017b) Digital Government Review of Norway. Boosting the Digital Transformation of the Public Sector. Paris, OECD Publishing https://www.oecd.org/gov/digitalgovernment/digital-government-review-norway-recommendations.pdf [Letöltve: 2019. 11. 17.]

RónAy Z. (2019) A hazai tanügyigazgatás jogszabályi keretei. Educatio, Vol. 28. No. 2. pp. 228-239.

Scriven, M. (1967) Series on Curriculum Evaluation. The Methodology of Evaluation. In: G. Tyler \& M. Scriven (eds) Perspectives of Curriculum Evaluation. Chicago, Rand McNally.

A cikk a Creative Commons Attribution 4.0 International License (https://creativecommons.org/licenses/ by/4.0/) feltételei szerint publikált Open Access közlemény, melynek szellemében a cikk bármilyen médiumban szabadon felhasználható, megosztható és újraközölhető, feltéve, hogy az eredeti szerző és a közlés helye, illetve a CC License linkje és az esetlegesen végrehajtott módosítások feltüntetésre kerülnek. (SID_1) 